Archives of Agriculture and Environmental Science

\title{
Genetic variability and cluster analysis of wheat (Triticum aestivum L.) genotypes in foot hill of Nepal
}

\author{
Koshraj Upadhyay ${ }^{1^{*}}$ iD , N.R. Adhikari ${ }^{1}$, G.B.K.C. ${ }^{2}$ and S. Sharma ${ }^{1}$
}

${ }^{1}$ Department of Plant Breeding, Institute of Agriculture and Animal Science, Tribhuwan University, Rampur Campus, Chitwan, NEPAL

${ }^{2}$ Department of Plant Pathology, Institute of Agriculture and Animal Science, Tribhuwan University, Rampur Campus, Chitwan, NEPAL

*Corresponding author's E-mail: agrikoshu83@gmail.com

\section{ARTICLE HISTORY}

Received: 02 September 2019

Revised received: 05 September 2019

Accepted: 07 September 2019

\section{Keywords}

Cluster

Genetic variability

Genetic advance

Heritability

Wheat (Triticum aestivum L.)

\section{ABSTRACT}

To study the variability in wheat (Triticum aestivum L.) genotypes and to identify the superior genotypes for yield and yield attributing traits, a field experiment was conducted during November 2017 to April 2018 at Kamalamai-04, Phant, of Sindhuli district, Nepal. Thirty wheat genotypes were experimented in Alpha lattice design with 3 replications. Observations for Days to heading, days to maturity, plant height, spike length, peduncle length, flag leaf area, no. of spikes $/ \mathrm{m}^{2}$, no of grains/spike, weight of kernel/spike, thousand kernel weight, grain yield and biological yield were recorded and analysis was done at 0.05 probability level. High broad sense heritability associated with high genetic advance over mean was observed for the traits, grain yield (90\%, 57.52\%), peduncle length (93\%, 52.58\%), plant height (88\%, 34\%), number of grains/spike (83\%, 39.76\%), thousand kernel weight (80\%, 36.75\%), kernel weight/spike (77\%, $51.76 \%)$ and number of spikes $/ \mathrm{m}^{2}(77 \%, 39.16 \%)$ which indicated the predominance of additive genes action in controlling the expression of these traits. UPGMA dendrogram grouped thirty genotypes into distinct five clusters. Genotypes of cluster II can be utilized for development of superior cultivar through breeding program. Among all genotypes NL 1336 was highest grain yielder with thousand kernel weight, number of grains/spike and kernel weight/spike higher than local check WK 1204. Therefore, genotypes NL 1336, BL 4837, WK 2884 and BL 4833 can be utilized in breeding program as parents for improvement of wheat lines and development of high yielding wheat variety.

(C)2019 Agriculture and Environmental Science Academy

Citation of this article: Upadhyay, K., Adhikari, N. R., G. B. K.C. and Sharma, S. (2019). Genetic variability and cluster analysis of wheat (Triticum aestivum L.) genotypes in foot hill of Nepal. Archives of Agriculture and Environmental Science, 4(3): 350-355, https://dx.doi.org/10.26832/24566632.2019.0403013

\section{INTRODUCTION}

Wheat (Triticum aestivum L.) is the main cereal crop of the world providing $35 \%$ of staple food with more calories and $20 \%$ of daily dietary protein to the world population than any other cereals. It is directly associated to food security, nutrition and rural livelihood of resource poor farmers in South Asia, including Nepal. Wheat is the number one winter cereal and the third most cultivated crop after rice and maize in Nepal. It is cultivated in rotation with rice and maize. It occupies 735,850 ha of land and has production of $1,879,191$ metric tons yielding 2,554
(MoALMC, 2018). It is widely adapted with its coverage in all the three agro-climatic zones of the country, ranging from sea level to 4000 masl. Though the wheat area was expanded over the last decade, its productivity is constrained by numerous biotic and abiotic stresses.

In Nepal wheat is second staple grain after rice in consumption. A report by Nepal Demographic and Health Survey (NDHS, 2016) clearly mentioned that the national household food security is only $48.2 \%$ whereas in rural areas the percentage is only about $38.8 \%$. Brief on the Food Security Situation in Nepal Reporting period: Mid-March to mid-July 2017 Ministry of 
Agricultural Development (MoAD) and World Food Programme (WFP) Nepal Food Security Monitoring System Nepal Khadhya Surakshya Anugaman Pranali (NeKSAP, 2017). Since food insecurity is directly linked with low production of the staple crops, we need to improve productivity of staple crops as much as possible. For increasing productivity increasing area is not possible so we need to focus on evolving superior varieties and better management practice. A plant breeder can use variability present in existing genotypes for constant improvement of the best available genotypes for further enhancement in their yield potential either directly or through improvement of various factors which contribute indirectly to higher yield. The breeding methodology chosen concisely so that it can incorporate the favorable changes either by selection or by hybridization. Nature and magnitude of genetic variability has tremendous advantage for starting any breeding program. Existence of substantial genetic variability is the basic material for developing plant of desired characters (Safi et al., 2017). The information about genetic parameters viz., genetic advance, heritability among the traits are effective for selection and to predict genetic progress in breeding program (Falconer and Mackay, 1996). The successful crop improvement program depends upon the presence of wide genetic diversity in existing germplasm (Harlan, 1976). Therefore, calculation of genetic variability present among the existing genotypes helps a plant breeder in selecting desirable parents for breeding program.

\section{MATERIALS AND METHODS}

\section{Description of study area}

The experiment was conducted at the farmer's field of Kamalamai-04, Phant, of Sindhuli district, Nepal, from November 2017 to April 2018. The research site was located at $27.647680 \mathrm{~N}$ latitude and $84.347500 \mathrm{E}$ longitude and at an altitude of 571 meters above sea level. Thirty wheat genotypes were used as plant material in this study (Table 1). Wheat seeds were obtained from National Wheat Research Program, Bhairahwa. The field study was executed in Alpha lattice design with three replications, each replication consisting 6 blocks with 5 plots in each block. Individual plot size was $3 \mathrm{~m} \times 2 \mathrm{~m}\left(6 \mathrm{~m}^{2}\right)$. Row to row spacing was $25 \mathrm{~cm}$ where 8 rows of $3 \mathrm{~m}$ length in each plot was made. The planting was done in November 27, 2017. The chemical fertilizers were applied at the rate of 120:60:60 kg NPK/ ha. First irrigation was done at the crown root initiation (CRI) stage second at the time of booting stage and third at grain filling stage.

\section{Estimation of genetic parameters}

Broad sense heritability

The broad sense heritability was calculated according to (Falconer, 1960)

$$
\text { Heritabiloty }\left(h^{2}\right)=\frac{\text { Gennotypic variance }\left(\sigma_{g}^{2}\right)}{\text { Phenotypic variance }\left(\sigma_{p}^{2}\right)}
$$

Genotypic and phenotypic variance were obtained from analysis of variance table according to (Sing and El-Bizri, 1992)

$\sigma_{g}^{2}=\frac{\text { Genotypic mean sum of square }- \text { Error mean sum of square }}{r}$
$\sigma_{p}^{2}=$ Genotypic mean sum of square + Error mean sum of square

The heritability was categorized as 0-30\%; low, 30-60\%; moderate, $60 \%$ and above; high heritability (Robinson et al., 1949).

Phenotypic and genotypic coefficient of variation

Phenotypic coefficient of variation (PCV) and genotypic coefficient of variation (GCV) were estimated according to (Sing and El-Bizri, 1992).

$$
\begin{aligned}
& \operatorname{GCV}(\%)=\frac{\sqrt{\sigma_{g}^{2}}}{X} * 100 \\
& \operatorname{PCV}(\%)=\frac{\sqrt{\sigma_{p}^{2}}}{X} * 100
\end{aligned}
$$

Where,

$$
\begin{aligned}
& \sigma_{g}^{2}=\text { genotypic variance } \\
& \sigma_{p}^{2}=\text { phenotypic variance }
\end{aligned}
$$

$\mathrm{X}=$ mean value of the trait; PCV and GCV were categorized as 0-10\%;low, 10-20\%; moderate and above 20\%; high (Sivasubramanian and Menon, 1973).

\section{Genetic advance}

Genetic advance was calculated as per the following formula

$$
G A=K * \sqrt{\sigma_{p}^{2}} * h^{2}
$$

Where,

$\mathrm{K}=$ Selection intensity $(5 \%=2.06)$; Genetic advance as $\%$ of mean was estimated according to (Hanson et al., 1956).

Genetic advance as $\%$ of mean $(\mathrm{GAM})=\frac{\mathrm{GA}}{\text { mean value of the trait }} * 100 \%$

Genetic advance ass \% of mean is categorized as $0-10 \%$ low GAM, $10-20 \%$ moderate GAM and above $20 \%$ high GAM (Johnson et al., 1955)

Statistical analysis

Collected data were processed to fit into $\mathrm{R} 3.4 .2$ and $R$ studio software for Analysis of Variance at 0.05 and 0.001 probability level. UPGMA clustering was done in MINITAB 14. 
Table 1. List of 30 wheat genotypes used in the study.

\begin{tabular}{|c|c|c|c|c|c|}
\hline Entry & Genotypes & Entry & Genotypes & Entry & Genotypes \\
\hline 1 & BL 4833 & 11 & NL 1334 & 21 & WK 2799 \\
\hline 2 & BL 4837 & 12 & NL 1335 & 22 & WK 2820 \\
\hline 3 & BL 4845 & 13 & NL 1336 & 23 & WK 2832 \\
\hline 4 & BL 4850 & 14 & NL 1337 & 24 & WK 2846 \\
\hline 5 & BL 4863 & 15 & NL 1338 & 25 & WK 2847 \\
\hline 6 & NL 1329 & 16 & NL 1339 & 26 & WK 2884 \\
\hline 7 & NL 1330 & 17 & NL 1340 & 27 & RR 21 \\
\hline 8 & NL 1331 & 18 & NL 1341 & 28 & Morocco \\
\hline 9 & NL 1332 & 19 & NL 1342 & 29 & Dhaulagiri \\
\hline 10 & NL 1333 & 20 & WK 2793 & 30 & WK1204 \\
\hline
\end{tabular}

RESULTS AND DISCUSSION

\section{Mean performance}

Genotypes differed significantly for all the studied traits except spike length (Table 2). Grain yield (ton/ha) on 30 varieties ranged from 2.16 ton/ha to 4.42 ton/ha. Significantly highest grain yield was found on NL 1336 (4.42 ton/ha) followed by BL 4837 (4.13 ton/ha) and in NL 1333 (2.16 ton/ha) had significantly lowest grain yield. Mean grain yield was found to be 3.17 ton/ ha from 30 genotypes. Except spike length all the studied eleven traits have sufficient variance is present (Table 2), which can be used in breeding program for improvement of those traits. In genotype NL 1336 highest number of grains per spike was found followed by WK 1204 (49.56) and BL 4837 (48.6). Genotype BL 4837 (2.64 g) has highest weight of kernel per spike followed by BL 4845 (2.3 g) and NL 1336 (2.23 g). Highest thousand kernel weight was found in genotype BL $4837(50.67 \mathrm{~g})$ followed by NL 1338 (46.33) and NL 1336 (46.33). The highest grain yielding genotype was NL 1336 (4.43 ton/ha), followed by BL 4837 (4.14 ton/ha) and WK 1204 (3.91 ton/ha).

Grain yield of wheat is a qualitative trait and is affected by polygenes to improve grain yield we have to improve yield attributing traits like; number of tillers $/ \mathrm{m}^{2}$, number of grains per spike, thousands kernel weight, and plant height and spike length. Wheat production can be increased through development of productive cultivars adapted to various agro-climatic conditions that resist all kinds of stresses. For improving yield of wheat enough genetic variability should present in existing variety that can be utilized in breeding program (Naik et al., 2015). There were significant differences among the genotypes for all the traits studied which are in agreement with Bhattarai et al. (2017), Pandey et al. (2017) Abebe and Desta (2017) and Naik et al. (2015) who reported high variability for different traits in wheat. Thus, it is implied that there was reasonably sufficient variability in the research material, which provides ample scope for selecting superior and desired genotypes by the plant breeder for further improvement.

\section{Estimation of genetic parameters}

The genetic parameters genotypic variance, phenotypic variance, environmental variance, broad sense heritability, phenotypic coefficient of variation, genotypic coefficient of variation, genetic advance of percentage of mean is presented in Table 3.

\section{Broad sense heritability}

Heritable genetic variation in targeted traits has great importance in crop genetic improvement. Hence the available genetic variation, heritability and expected genetic gain are useful to develop better breeding strategies (Jalata et al., 2011). Grain yield is a polygenic trait having low heritability and often affected by environment, so the selection for grain yield is difficult (Riaz and Chowdhry, 2003). The genotypic coefficient of variation and heritability estimates give the scope of genetic advance to be expected through phenotypic selection. Moderate to high heritability was found for different traits recorded. High heritability was found for Peduncle length (93.38\%), grain yield (90.53\%), flag leaf area (88.57\%), plant height $(88.26 \%)$, Days to heading (88.03\%), no. of grains/spike (83.06\%), thousand kernel weight (80.17\%), kernel weight/ spike (77.36\%). Comparatively low heritability was found in spike length (49.50) (Table 3).

\section{Genotypic and phenotypic coefficient of variation}

The results showed considerable phenotypic and genotypic variances among the experimented genotypes for the characters under consideration. The value of GCV was high for flag leaf area (54.23), grain yield (29.35), kernel weight/spike (28.57), peduncle length (26.41), no. of spike/ $\mathrm{m}^{2}$ (21.60), no. of grains/ spike (21.18) moderate GCV was found for thousand kernel weight (19.92), plant height (18.06) and spike length (14.33). The PCV was also high for flag leaf area (57.61), kernel weight/ spike (32.48), grain yield (30.84), peduncle length (27.33), no. of spikes $/ \mathrm{m}^{2}$ (24.54), no. of grains per spike (23.23) thousand kernel weight (22.25), spike length (20.37) and moderate PCV was found for plant height (19.22). (Table 3). The PCV was found higher than GCV for each trait but the difference between PCV and GCV is less which shows less environmental effects on the trait expression. Higher deviation from GCV to PCV was seen in spike length, weight of kernel/spike, flag leaf area, thousands kernel weight, no. of spikes $/ \mathrm{m}^{2}$ and no. of grains/spike than grain yield, plant height and peduncle length (Table 3). Almost equal magnitude of GCV and PCV was found for peduncle length, plant height and grain yield this indicates that these characters were less influenced by environments. While, number of grains/ 
spike, thousand kernel weight, number of spike $/ \mathrm{m}^{2}$, flag leaf area, weight of kernel/spike and spike length showed high values of $P C V$ over GCV value indicating large amount of variation for these characters were due to environments only. Mesele et al. (2016) reported high deviation of PCV with GCV for the traits spike length, no. of kernel per spike, grain yield and biological yield and less deviation of PCV to GCV for the trait thousand kernel weight. Naik et al. (2015) reported less deviation of GCV to PCV for parameters yield, thousand kernel weight, days to heading, plant height and high deviation is seen for spike length. Ali and Al (2008) observed less deviation of PCV and GCV for the traits plant height and thousand kernel weight while high deviation was seen for spike length, no. of grains per spike and grain yield. For spike length, number of grains per spike high environment influence is seen while less influence of environment was seen for trait thousand kernel weight and the expression of traits like yield, biological yield is dependent to the type of environment.

\section{Genetic advance as percentage of mean}

Highest GAM was found in leaf area index (105.13), grain yield (57.51), peduncle length (52.58) and weight of kernel/spike (51.76), number of grains/spike (39.76), number of spikes $/ \mathrm{m}^{2}$ (39.16), thousand kernel weight (36.75), plant height (34.95) and low GAM was found for the trait spike length (20.77) (Table 3). Assessment of heritability and genetic advance are crucial for predicting genetic improvement for quantitative trait. Heritability estimates shows the effectiveness of selection for phenotypic performance of particular character. The heritability estimates along with high genetic advance is more useful for the selection (Singh et al., 2017).

In present study high heritability coupled with high genetic advance over mean was observed for the traits grain yield, peduncle length, plant height, number of grains/spikes, thousand kernel weight, kernel weight/spike and spike per $\mathrm{m}^{2}$ (Table 3). Naik et al. (2015) observed high broad sense heritability and genetic advance for the traits grain yield (97\%, 104.91\%), thousand kernel weight $(94 \%, 36.66 \%)$, plant height $(99 \%$, 27.04\%), and spike length (76\%, 21.51\%). According to (Ali and Al, 2008a) high heritability and GAM was found of the traits yield (64\%, 68.13\%), TKW (99.5\%, 24.21\%), PH (84.8\%, $20.83 \%)$, spike length $(76.2 \%, 26.7 \%)$, grains per spike $(69 \%$, 36.71\%). (Naik et al., 2015) and (Ali and Al, 2008a) have similar type of result with the present findings which indicates the predominance of additive genes action in controlling the expression of these traits. Therefore, response to selection could be anticipated in improving these traits. The trait spike length showed moderate heritability with moderate GAM.

Table 2. Mean performance of penological and yield attributing traits of 30 wheat genotypes during November 2017 to April 2018 at Kamalamai-04, Phant, Sindhuli.

\begin{tabular}{|c|c|c|c|c|c|c|c|c|c|c|c|c|}
\hline Genotypes & $\begin{array}{c}\mathrm{PH} \\
(\mathrm{cm})\end{array}$ & $\begin{array}{l}\text { FLA } \\
\left(\mathrm{cm}^{2}\right)\end{array}$ & $\begin{array}{c}\mathrm{SL} \\
(\mathrm{cm})\end{array}$ & $\begin{array}{c}\mathrm{PL} \\
(\mathrm{cm})\end{array}$ & $\mathrm{DH}$ & MD & NSPM & NGPS & $\begin{array}{l}\text { KWP } \\
\text { S (g) }\end{array}$ & $\begin{array}{c}\text { TKW } \\
\text { (g) }\end{array}$ & $\begin{array}{c}G Y \\
\text { (t/ha) }\end{array}$ & $\begin{array}{c}\text { BY } \\
\text { (t/ha) }\end{array}$ \\
\hline $\begin{array}{l}\text { Grand } \\
\text { mean }\end{array}$ & 77.96 & 19.07 & 8.98 & 34.94 & $\begin{array}{c}84.2 \\
5\end{array}$ & 128.85 & 268.03 & 41.6 & 1.83 & 39.77 & 3.16 & 8.86 \\
\hline Range & $\begin{array}{l}112 .- \\
65.2\end{array}$ & $\begin{array}{l}9.5- \\
35.7\end{array}$ & $\begin{array}{l}7.4- \\
10.5\end{array}$ & $\begin{array}{l}55.6- \\
26.3\end{array}$ & $\begin{array}{l}73- \\
93.3\end{array}$ & $\begin{array}{c}121.4- \\
135.2\end{array}$ & $\begin{array}{l}192.4- \\
325.6\end{array}$ & $\begin{array}{c}31.1- \\
51.9\end{array}$ & $\begin{array}{l}1.3- \\
2.6\end{array}$ & $\begin{array}{l}29.7- \\
50.7\end{array}$ & $2.2-4.4$ & $\begin{array}{l}6.5- \\
11.2\end{array}$ \\
\hline CV\% & 5.68 & 17.24 & 13.37 & 7.64 & 3.55 & 1.30 & 12.2 & 7.6 & 12.78 & 9.31 & 9.61 & 13.98 \\
\hline LSD & 8.55 & 6.18 & & 4.09 & 5.82 & 2.44 & 52.03 & 6.27 & 0.46 & 6.56 & 0.5 & 2.25 \\
\hline F test & $* * *$ & *** & Ns & $* * *$ & $* * *$ & $* * *$ & $* * *$ & $* * *$ & $* * *$ & $* * *$ & $* * *$ & $*$ \\
\hline
\end{tabular}

$\mathrm{PH}=$ plant height, $\mathrm{FLA}=$ flag leaf area, $\mathrm{SL}=$ spike length, $\mathrm{PL}=$ peduncle length, $\mathrm{DH}=$ days to heading, $\mathrm{MD}=$ maturity days, $\mathrm{NSPM}=\mathrm{No}$ of $\mathrm{spikes} / \mathrm{m}^{2}$, NGPS $=$ No of grains/spike, KWPS= Kernel weight/spike, TKW= Thousand kernel weight, GY= Grain yield, BY= Biological yield; Significant traits are denoted by ${ }^{*}$ for $p<.05,{ }^{* *}$ for $p<.01$, and ${ }^{* * *}$ for $P<0.001$.

Table 3. Estimation of heritability, phenotypic coefficient of variation, genetic coefficient of variation and genetic advance as percentage of mean of 30 wheat genotypes during November 2017 to April 2018 at Kamalamai-04, Phant, Sindhuli.

\begin{tabular}{lccccccc}
\hline Traits & GV & PV & EV & BSH & PCV (\%) & GCV (\%) & GAM (\%) \\
\hline Days to heading & 90.14 & 102.39 & 12.25 & 0.88 & 12.01 & 11.27 & 21.78 \\
Days to maturity & 33.01 & 35.15 & 2.15 & 0.93 & 4.60 & 4.458 & 8.9 \\
Plant height $(\mathrm{cm})$ & 198.21 & 224.56 & 26.36 & 0.88 & 19.22 & 18.06 & 34.95 \\
No of spike $/ \mathrm{m}^{2}$ & 3352.67 & 4328.67 & 976 & 0.77 & 24.55 & 21.60 & 39.16 \\
Spike length $(\mathrm{cm})$ & 1.66 & 3.35 & 1.69 & 0.49 & 20.37 & 14.33 & 20.77 \\
Peduncle length $(\mathrm{cm})$ & 85.23 & 91.27 & 6.04 & 0.93 & 27.33 & 26.41 & 52.58 \\
No. of grains/spike & 77.63 & 93.46 & 15.83 & 0.83 & 23.24 & 21.18 & 39.76 \\
Kernel wt./spike (g) & 0.27 & 0.35 & 0.08 & 0.77 & 32.48 & 28.57 & 51.76 \\
TKW (g) & 62.83 & 78.37 & 15.54 & 0.80 & 22.25 & 19.92 & 36.75 \\
Grain yield (ton/ha) & 0.86 & 0.95 & 0.09 & 0.90 & 30.84 & 29.35 & 57.52
\end{tabular}

$\mathrm{GV}=$ Genotypic variance; $\mathrm{PV}=$ Phenotypic variance; $\mathrm{EV}=$ environmental variance; $\mathrm{BSH}=$ Broad sense heritability $\mathrm{PCV}=\mathrm{Phenotypic}$ coefficient of variation; $\mathrm{GCV}=$ genotypic coefficient variation $\mathrm{GAM}=$ Genetic advance as percentage of mean. 
Table 4. Distance between different cluster centroids of 30 wheat genotypes during November 2017 to April 2018 at Kamalamai-04, Phant, Sindhuli.

\begin{tabular}{llllll}
\hline & Cluster 1 & Cluster 2 & Cluster 3 & Cluster 4 & Cluster 5 \\
\hline Cluster 1 & 0 & & & & \\
Cluster 2 & 145.31 & 0 & & & \\
Cluster 3 & 59.06 & 103.93 & 0 & 0 & \\
Cluster 4 & 88.34 & 65.23 & 39.13 & 35.58 & 0 \\
Cluster 5 & 119.49 & 30.54 & 74.44 & & \\
\hline
\end{tabular}

Dendrogram with Average Linkage and Euclidean Distance

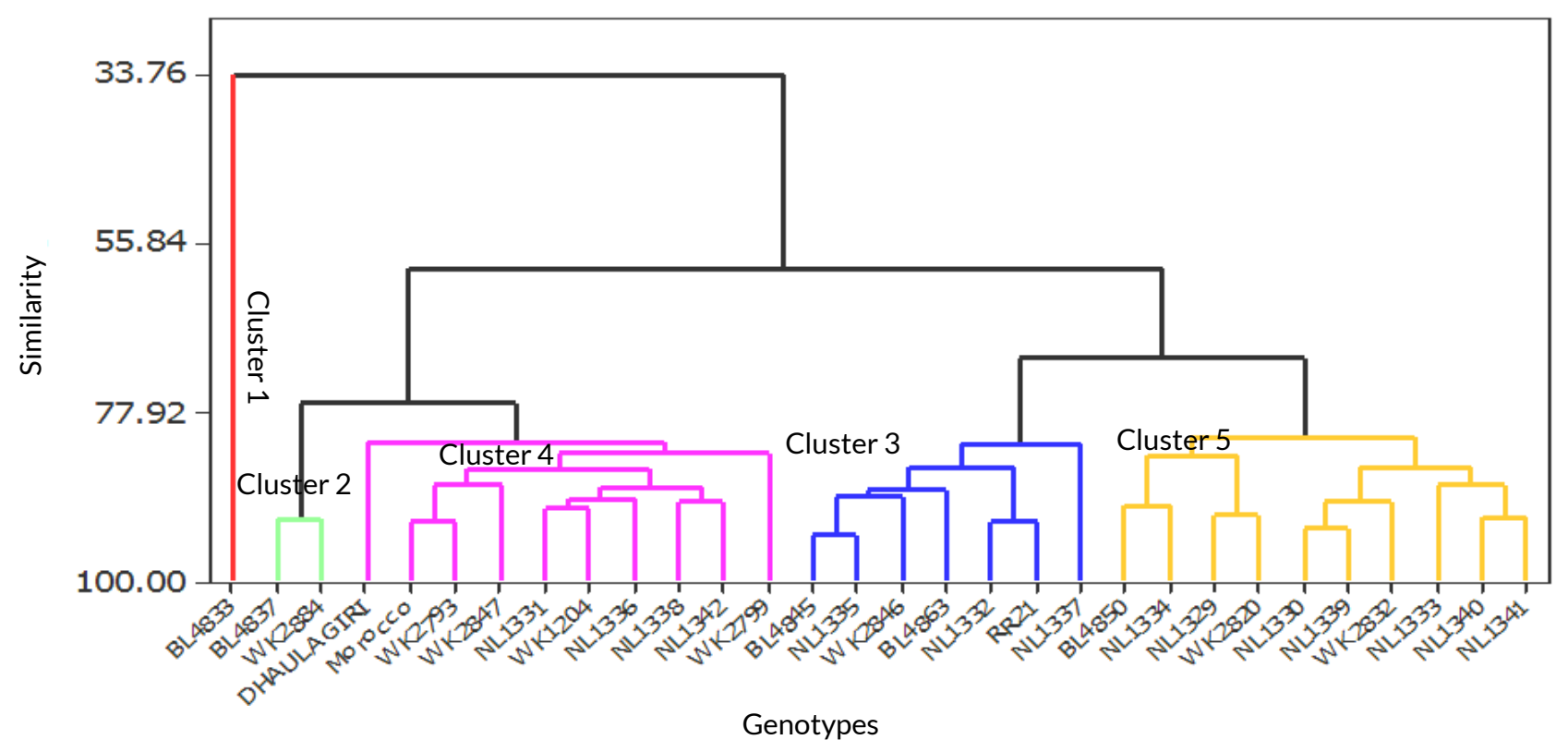

Figure 1. UPGMA cluster analysis of 30 wheat Genotypes during November 2017 to April 2018 at Kamalamai-04, Phant, Sindhuli.

Multivariate analysis

\section{Cluster analysis}

The cluster analysis based on grain yield, biological yield, thousand kernel weight, flag leaf area, plant height, number of spikes/ $\mathrm{m}^{2}$, spike length, peduncle length, number of grains/spikes, kernel weight/spike, heading days and maturity days divided the genotypes in 5 different clusters (Table 4; Figure 1). Cluster I there is only one genotype $\mathrm{BL} 4833$ and this cluster represents highest, flag leaf area, plant height, spike length, peduncle length and grains weight per spike. For higher plant height, grains weight per spike, flag leaf area and spike length this BL 4833 genotype can be selected. Cluster II consists of 2 genotypes with highest yield and other yield attributing traits. These genotypes (BL 4837 and WK 2884) could be selected for achieving highest grain yield, biomass yield, thousand kernel weight, number of grains per spike and number of spikes per $\mathrm{m}^{2}$. This cluster is superior for all the economic traits like grain yield, number of grains/spikes, thousand kernel weight, biological yield etc. genotypes of this cluster are late maturing type hence they get maximum grain filling period resulting higher grain yield. Cluster III has 7 genotypes BL 4845, NL 1335, NL 1332, BL 4863, WK 2846, NL 1337 and RR 21. This cluster has low thousand kernel weight. Cluster IV has 10 genotypes. Dhaulagiri, WK 1204, NL 1336, NL 1338, NL 1342, WK 2793, WK 2847, Morocco, NL 1331 and WK 2799. This cluster has lowest grain yield. Cluster $V$ has also 10 genotypes, BL 4850, NL 1339, WK 2820, NL 1333, WK 2832, NL 1330, NL 1329, NL 1334, NL 1340 and NL 1341.
Conclusion

Sufficient variation was observed among genotypes for the studied traits which can be exploited for improvement of the existing genotypes for targeted traits and environment. Genotypes of cluster I, II and III can be utilized in breeding program for hybridization since those cluster are distantly related. The difference between PCV and GCV is less which shows high expressivity of those genotypes in that environment. High heritability associated with high genetic advance provides positive response of genotypes in selection for improvement of traits like grain yield, peduncle length, plant height, number of grains/spikes, thousand kernel weight, kernel weight/spike and spike per $\mathrm{m}^{2}$. Among all genotypes NL 1336 was highest grain yielder with thousand kernel weight, number of grains/spike and kernel weight/spike higher than local check WK 1204. Hence, these findings will help in breeding program for the development of desirable variety having superior traits.

\section{ACKNOWLEDGEMENTS}

We are grateful to Mr. Khem Raj Pant, T6, NWRP for providing valuable suggestions and ideas during research. We are thankful to National Agriculture Research and Development Fund (NARDF) for providing financial support to carry out this research work and National Wheat Research Program (NWRP) for research materials. 


\section{Conflict of interest}

The authors declare there are no conflicts of interest.

Open Access: This is an open access article published under the terms and conditions of Creative Commons AttributionNonCommercial 4.0 International License which permits noncommercial use, distribution, and reproduction in any medium, provided the original author(s) if the sources are credited.

\section{REFERENCES}

Abebe, A.A. and Desta, T.M. (2017). Genetic variability and character association of some local wheat varieties (Triticum species) using agromorphological traits grown in South Gondar zone, Ethiopia, 16(44): 2100-2105, https://doi.org/10.5897/AJB2015.15018

Ali, Y. and Al, E.T. (2008). Genetic variability, association and diversity studies in wheat (Triticum aestivum L.) Germplasm, 40: 2087-2097.

Bhattarai, R.P., Ojha, B.R., Thapa, D.B., Kharel, R., Ojha, A. and Sapkota, M. (2017). Evaluation of elite spring wheat (Triticum aestivum L.) genotypes for yield and yield attributing traits under irrigated condition. International Journal of Applied Sciences and Biotechnology, 5(2): 194, https://doi.org/10.3126/ijasbt.v5i2.17615

Falconer, D.S. (1960). Introduction to Quantitative Genetics (First). New York: The Ronald Press Company.

Falconer, D.S. and Mackay, T.F.C. (1996). Quantitative Genetics. (Fourth Edition).

Hanson, C., Robinson, H. and Comstock, R. (1956). Biometrical studies of yield in segregating populations of Korean Lespedeza. Agronomy Journal, 48(6): 268-272.

Harlan, J.R. (1976). Genetic resources in wild relatives of crops. Crop Science, 16 (3): 329, https://doi.org/10.2135/cropsci1976.0011183x001600030004x

Jalata, Z., Ayana, A. and Zeleke, H. (2011). Variability, heritability and genetic advance for some yield and yield related trates in ethiopian barley (Hordeum vulgare L.) landraces and crosses. International Journal of Plant Breeding and Genetics, 5(1): 44-52, https://doi.org/10.3923/ijpbg.2011.44.52
Johnson, H.W., Robinson, H. and Comstock, R. (1955). Estimates of genetic and environmental variability in soybeans. Agronomy Journal, 47(7): 314-318.

Mesele, A., Mohammed, W. and Dessalegn, T. (2016). Estimation of heritability and genetic advance of yield and yield related traits in bread wheat (Triticum aestivum L.) genotypes at Ofla District, Northern Ethiopia. International Journal of Plant Breeding and Genetics, 10(1): 31-37, https://doi.org/10.3923/ijpbg.2016.31.37

MoALMC, Ministry of Agriculture Land Management and Cooperatives. (2018). Statistical Information on Nepalese Agriculture.

Naik, V.R., Biradar, S.S., Yadawad, A., Desai, S.A. and Veeresha, B.A. (2015). Study of genetic variability parameters in bread wheat (Triticum aestivum L.) genotypes. Research Journal of Agricultural Sciences, 6(1): 123-125.

NDHS (2016). Nepal Demographic and Health Survey.

NeKSAP (2017). Nepal Khadhya Surakshya Anugaman Pranali (NeKSAP) with support from UK aid from the UK government.

Pandey, G., Yadav, L., Tiwari, A., Khatri, H.B., Bhattarai, K., Gyawali, B. and Khatri, N. (2017). Analysis of yield attributing characters of different genotypes of wheat in Rupandehi, Nepal. International Journal of Environment, Agriculture and Biotechnology, 5: 2374-2379, http://dx.doi.org/10.22161/ijeab/2.5.13

Riaz, R. and Chowdhry, M.A. (2003). Estimation of variation and heritability of some physio-morphic traits of wheat under drought condition. Asian Journal of Plant Science, 2(10): 748-755.

Robinson, H.F., Comstok, R.E. and Harvey, P.H. (1949). Estimates of heritability and the degree of dominance in corn. Agronomy Journal, 41: 353-359, https://doi.org/10.2134/agronj1949.00021962004100080005x

Safi, L., Singh, R. and Abraham, T. (2017). Assessment of heritability and genetic parameters in wheat (Triticum aestivum L.) based on agronomic and morphological traits, 6(5): 18-21.

Sing, M. and El-Bizri, K.S. (1992). Phenotypic correlation: Its estimation and testing significance. Biometrical Journal, 34(2): 165-171, https://doi.org/10.1002/bimj.4710340206

Singh, R., Mahmoudpour, A., Rajkumar, M. and Narayana, R. (2017). A review on stripe rust of wheat, its spread, identification and management at field level. Research on Crops, 18(3): 528, https://doi.org/10.5958/2348-7542.2017.00091.2 